\title{
Environmental controls on nitrogen and sulfur cycles in surficial aquatic sediments
}

\author{
Chuanhui Gu ${ }^{1}$, Anniet M. Laverman ${ }^{2 *}$ and Céline E. Pallud ${ }^{3}$ \\ ${ }^{1}$ Department of Geology, Appalachian State University, Boone, NC, USA \\ ${ }^{2}$ UMR 7619 Sisyphe, CNRS - Université Pierre et Marie Curie, 75005 Paris, France \\ ${ }^{3}$ Environmental Science, Policy and Management, University of California, Berkeley, CA, USA
}

Edited by:

Paul Bodelier, Netherlands Institute of

Ecology, Netherlands

\section{Reviewed by:}

Nick Bouskill, Lawrence Berkeley

National Laboratory, USA

Suzanne Caroline Marianne Haaijer,

Radboud University Nijmegen,

Netherlands

${ }^{*}$ Correspondence:

Anniet M. Laverman, UMR 7619

Sisyphe, Université Pierre et Marie Curie, 75005 Paris, France.

e-mail:Anniet.Laverman@upmc.fr
Enhanced anthropogenic inputs of nitrogen $(\mathrm{N})$ and sulfur $(\mathrm{S})$ have disturbed their biogeochemical cycling in aquatic and terrestrial ecosystems. The $\mathrm{N}$ and $\mathrm{S}$ cycles interact with one another through competition for labile forms of organic carbon between nitrate-reducing and sulfate-reducing bacteria. Furthermore, the $\mathrm{N}$ and $\mathrm{S}$ cycles could interact through nitrate $\left(\mathrm{NO}_{3}^{-}\right)$reduction coupled to $\mathrm{S}$ oxidation, consuming $\mathrm{NO}_{3}^{-}$, and producing sulfate $\left(\mathrm{SO}_{4}^{2-}\right)$. The research questions of this study were: (1) what are the environmental factors explaining variability in $\mathrm{N}$ and $\mathrm{S}$ biogeochemical reaction rates in a wide range of surficial aquatic sediments when $\mathrm{NO}_{3}^{-}$and $\mathrm{SO}_{4}^{2-}$ are present separately or simultaneously, (2) how the $\mathrm{N}$ and $\mathrm{S}$ cycles could interact through $\mathrm{S}$ oxidation coupled to $\mathrm{NO}_{3}^{-}$reduction, and (3) what is the extent of sulfate reduction inhibition by nitrate, and vice versa. The $\mathrm{N}$ and $\mathrm{S}$ biogeochemical reaction rates were measured on intact surface sediment slices using flow-through reactors. The two terminal electron acceptors $\mathrm{NO}_{3}^{-}$and $\mathrm{SO}_{4}^{2-}$ were added either separately or simultaneously and $\mathrm{NO}_{3}^{-}$and $\mathrm{SO}_{4}^{2-}$ reduction rates as well as $\mathrm{NO}_{3}^{-}$reduction linked to $\mathrm{S}$ oxidation were determined. We used redundancy analysis, to assess how environmental variables were related to these rates. Our analysis showed that overlying water $\mathrm{pH}$ and salinity were two dominant environmental factors that explain $58 \%$ of the variance in the $\mathrm{N}$ and $\mathrm{S}$ biogeochemical reaction rates when $\mathrm{NO}_{3}^{-}$and $\mathrm{SO}_{4}^{2-}$ were both present. When $\mathrm{NO}_{3}^{-}$and $\mathrm{SO}_{4}^{2-}$ were added separately, however, sediment $\mathrm{N}$ content in addition to $\mathrm{pH}$ and salinity accounted for $62 \%$ of total variance of the biogeochemical reaction rates. The $\mathrm{SO}_{4}^{2-}$ addition had little effect on $\mathrm{NO}_{3}^{-}$reduction; neither did the $\mathrm{NO}_{3}^{-}$addition inhibit $\mathrm{SO}_{4}^{2-}$ reduction. The presence of $\mathrm{NO}_{3}^{-}$led to $\mathrm{SO}_{4}^{2-}$ production most likely due to the oxidation of sulfur. Our observations suggest that metal-bound $\mathrm{S}$, instead of free sulfide produced by $\mathrm{SO}_{4}^{2-}$ reduction, was responsible for the $\mathrm{S}$ oxidation.

Keywords: aquatic sediments, denitrification, sulfate reduction, sulfide oxidation, salinity, salt marsh, estuarine sediments, wetland soils

\section{INTRODUCTION}

Human-induced disturbances to the nitrogen $(\mathrm{N})$ and sulfur $(\mathrm{S})$ biogeochemical cycles, resulting for instance from atmospheric deposition and agricultural activities, have altered the global storage and fluxes of those elements (Schlesinger, 1997; Galloway et al., 2008). More specifically, the $\mathrm{N}$ and $\mathrm{S}$ loadings to aquatic ecosystems have increased dramatically due to anthropogenic activities in recent decades (Schlesinger, 1997), which lead to intensified interactions between the $\mathrm{N}$ and $\mathrm{S}$ cycles. For example, increased $\mathrm{N}$ loading associated with coastal development may lead to overlapping zones of abundant $\mathrm{N}$ and $\mathrm{S}$ in tidal creeks and salt marsh estuaries (Howarth et al., 1996). Furthermore, S content in freshwater ecosystems used to be too low (Holmer and Storkholm, 2001) for interactions between the $\mathrm{N}$ and $\mathrm{S}$ cycles to play a significant role in the biogeochemical cycles of those elements in such systems. However, salt water intrusion due to frequent hurricanes and storm surge caused by climate change in coastal areas (Ericson et al., 2006) have resulted in an increase in S concentrations in freshwater systems. Furthermore, whereas atmospheric $\mathrm{S}$ deposition from fossil fuel burning has decreased in North America and Europe due to air pollution control measures (Mayewski et al., 1990; Fischer et al., 1998), it is still important in southern Asia (Duan et al., 2007). There is consequently a pressing need to understand how biogeochemical processes constitutive of the $\mathrm{N}$ and $\mathrm{S}$ cycles will interact with one another in these human-altered environments. The $\mathrm{N}$ and $\mathrm{S}$ cycles are driven by microbially mediated reactions affecting the redox states of both elements, and consequently their mobility and availability. Among them, denitrification converts nitrate $\left(\mathrm{NO}_{3}^{-}\right)$to dinitrogen gas $\left(\mathrm{N}_{2}\right)$, effectively removing $\mathrm{N}$ from the soluble and bioavailable pools (Knowles, 1982). Similarly, S cycling in anoxic aquatic sediments involves both reductive and oxidative processes (Holmer and Storkholm, 2001). Both $\mathrm{NO}_{3}^{-}$and sulfate $\left(\mathrm{SO}_{4}^{2-}\right)$ are commonly used as terminal electron acceptors (TEA) for microbial respiration in anoxic sediments, with $\mathrm{NO}_{3}^{-}$being energetically more favorable than $\mathrm{SO}_{4}^{2-}$ (Froelich et al., 1979). Whereas nitrate reduction is 
a widespread process carried out by members of the alpha, beta, gamma, and epsilon Proteobacteria, Gram-positive Bacteria, and Archaea (Zumft, 1997; Philippot, 2002), sulfate reduction is more specialized and restricted to members of the delta Proteobacteria and Archaea (Wagner et al., 1998; Muyzer and Stams, 2008). Whether as a competitive or inhibitory phenomenon, a decrease in sulfate reduction has been reported upon nitrate addition (Westermann and Ahring, 1987; Whitmire and Hamilton, 2005). Sulfide as the final product of sulfate reduction can be microbially oxidized coupled to nitrate, manganese, and iron reduction in anoxic environments or rapidly incorporated into minerals such as iron monosulfides $(\mathrm{FeS})$ and pyrite $\left(\mathrm{FeS}_{2}\right)$ (Thamdrup et al., 1994). An important interaction between the $\mathrm{N}$ and the $\mathrm{S}$ cycles is denitrification coupled with biotic sulfide oxidation (Brettar and Rheinheimer, 1991; Garciagil and Golterman, 1993; Burgin and Hamilton, 2007). The biogeochemical importance of $\mathrm{NO}_{3}^{-}$ use by $\mathrm{S}$-oxidizing bacteria has been widely recognized in marine sediments (Brettar and Rheinheimer, 1991) as well as freshwater sediments (Brunet and GarciaGil, 1996; Whitmire and Hamilton, 2005) and groundwater systems (Engesgaard and Kipp, 1992; Jorgensen et al., 2009). This process is used to mitigate toxic sulfide production in organic-rich sludge through $\mathrm{NO}_{3}^{-}$- mediated sulfide oxidation (Schwermer et al., 2010). Vice versa, elemental sulfur has also been applied to wastewater treatment to remove $\mathrm{NO}_{3}^{-}$by coupled sulfur oxidation and $\mathrm{NO}_{3}^{-}$reduction (Sierra-Alvarez et al., 2007).

Numerous studies have investigated the environmental (physical and biogeochemical) factors controlling the $\mathrm{N}$ and $\mathrm{S}$ cycling to better understand the processes involved, interpret the observed rates, and extrapolate them across temporal and spatial scales (Cornwell et al., 1999; Seitzinger et al., 2006; Wallenstein et al., 2006; Burgin and Hamilton, 2007). Most of those studies however, have examined the $\mathrm{N}$ and $\mathrm{S}$ cycling separately, either on individual sites or single ecosystem and the controls vary across systems. Therefore, the goal of the present study was to investigate the environmental factors controlling $\mathrm{N}$ and $\mathrm{S}$ biogeochemical reaction rates in a range of littoral sediments. For that purpose we compared fourteen surficial aquatic sediments from lakes, rivers, estuaries, salt marshes, and marine coastal sites that were characterized by a wide range of water salinity, $\mathrm{pH}, \mathrm{NO}_{3}^{-}$, and $\mathrm{SO}_{4}^{2-}$ concentration, as well as sediment porosity, organic carbon $\left(\mathrm{C}_{\mathrm{org}}\right), \mathrm{N}$, Arsenic (As), and iron (Fe) contents. We subsequently investigated possible interactions between the $\mathrm{N}$ and $\mathrm{S}$ cycles via comparison of $\mathrm{N}$ and $\mathrm{S}$ biogeochemical reaction rates measured when $\mathrm{NO}_{3}^{-}$and $\mathrm{SO}_{4}^{2-}$ were present separately or concomitantly. Understanding the effects of environmental parameters on the coupled $\mathrm{N}$ and $\mathrm{S}$ cycles will help us elucidate potential mechanisms that lead to this coupling and generalize our findings across ecosystems types.

\section{MATERIALS AND METHODS STUDY SITES}

We conducted a multi-site study, investigating surficial sediments from 14 aquatic systems ranging from freshwater to hypersaline in the USA and Europe. Identical analytical methods were used at all sites and a large number of water and sediment physical and chemical characteristics were measured as described below. The sites include temperate lakes, rivers, salt marshes, estuaries, and marine coastal waters in France, the Netherlands, and the USA (California; see Table 1). Sites were selected to encompass a range of salinities, as well as $\mathrm{NO}_{3}^{-}$and $\mathrm{SO}_{4}^{2-}$ concentrations in sediment overlying waters. We sampled two freshwater sites (Tresmes, Créteil), eight estuarine and salt marsh sites covering brackish (Elkhorn Slough, Elkhorn Slough Marsh, Waarde), brackish/saline conditions (Pescadero, Baylands) and saline conditions (Hourdel Port, Hourdel Salt Marsh, Rattekaai), two marine sites (Humboldt Bay and North CA Coast) and two hypersaline sites (Mono Lake Boat Launch and Mono Lake Black Point). Intact surficial sediment cores ( $4.2 \mathrm{~cm}$ inside diameter) were collected from each site and samples corresponding to the top $1 \mathrm{~cm}$ of the sediments were used for the flow-through experiments and physico-chemical characterization (except North CA Coast and Humboldt Bay where the top $2 \mathrm{~cm}$ were used). All estuarine sediments were sampled by hand in intertidal mudflats. River and lake sediments were sampled by hand 1-2 $\mathrm{m}$ from the river bank in water depths no greater than $0.5 \mathrm{~m}$ to avoid surface perturbations and sediment resuspension. Marine sediments from the North California (CA) Coast and Humboldt Bay were sampled from a ship at water depths of 70 and $10 \mathrm{~m}$, respectively, using a bottom grab device that left the sediment surface intact. All sediment samples were transported and stored at $4^{\circ} \mathrm{C}$ under anoxic conditions for 1-3 days until the experiments started.

\section{WATER AND SEDIMENT CHARACTERIZATION}

$\mathrm{NO}_{3}^{-}$, nitrite $\left(\mathrm{NO}_{2}^{-}\right)$, and ammonium $\left(\mathrm{NH}_{4}^{+}\right)$concentrations in liquid samples were measured colorimetrically on a Nutrient Autoanalyzer 3 (Bran and Luebbe). $\mathrm{SO}_{4}^{2-}$ concentrations in liquid samples were measured by ion chromatography (IC, Dionex DX$120)$. Sediment porosity was calculated from the dry bulk density $\left(\rho_{\mathrm{d}}\right)$ and particle density $\left(\rho_{\mathrm{s}}\right)$ as $1-\left(\rho_{\mathrm{d}} / \rho_{\mathrm{s}}\right)$, with $\rho_{\mathrm{d}}$ determined from the weight loss of a known volume of wet sediment sample after drying (2 days at $105^{\circ} \mathrm{C}$ or freeze drying). $\mathrm{C}_{\text {org }}$, total $\mathrm{N}$ and total $\mathrm{S}$ contents were determined using a Carlo Erba $\mathrm{CN}$ analyzer. Mean grain size of bulk sediment was determined with a Malvern Instruments Mastersizer $\mathrm{S}$, after removal of organic matter (with $6 \% \mathrm{H}_{2} \mathrm{O}_{2}$ ) and carbonate (with $1 \mathrm{~N} \mathrm{HCl}$ ), followed by chemical (in $4.5 \% \mathrm{Na}_{4} \mathrm{P}_{2} \mathrm{O}_{7}+4.2 \% \mathrm{Na}_{2} \mathrm{CO}_{3}$ ) and ultrasonic dispersion. As and Fe were extracted from sediments after $0.2 \mathrm{~g}$ freeze dried samples were digested in $10 \mathrm{~mL} 2 \mathrm{M}$ trace metal grade $\mathrm{HCl}$ for $24 \mathrm{~h}$. Total As concentrations were determined by graphite furnace atomic absorption spectrometry (GFAAS) on a Unicam_989 QZ spectrometer. Total Fe concentrations were determined by a flame atomic absorption spectrometer and a solar S spectrometer.

\section{FLOW THROUGH REACTOR EXPERIMENTS}

Steady-state reaction rates [e.g., maximum potential nitrate and sulfate reduction rates, and nitrite and ammonium production rates] were measured on intact sediment slices using recently developed flow-through reactors (FTRs; Roychoudhury et al., 1998; Laverman et al., 2006; Pallud and Van Cappellen, 2006; Pallud et al., 2007). Undisturbed surface sediment slices were collected directly in Plexiglas ${ }^{\circledR}$ reactor cells $(4.2 \mathrm{~cm}$ inside diameter and 1 or $2 \mathrm{~cm}$ long) between June 2006 and July 2008. Input solutions were supplied to the reactors at a constant flow rate $\left(Q=2 \pm 0.15 \mathrm{~mL} \mathrm{~h}^{-1}\right)$ using peristaltic pumps, and the reactor 
Table 1 | Surface water and sediment characteristics of 14 study sites in USA (California) and Europe; the Netherlands (NL) and France (Fr).

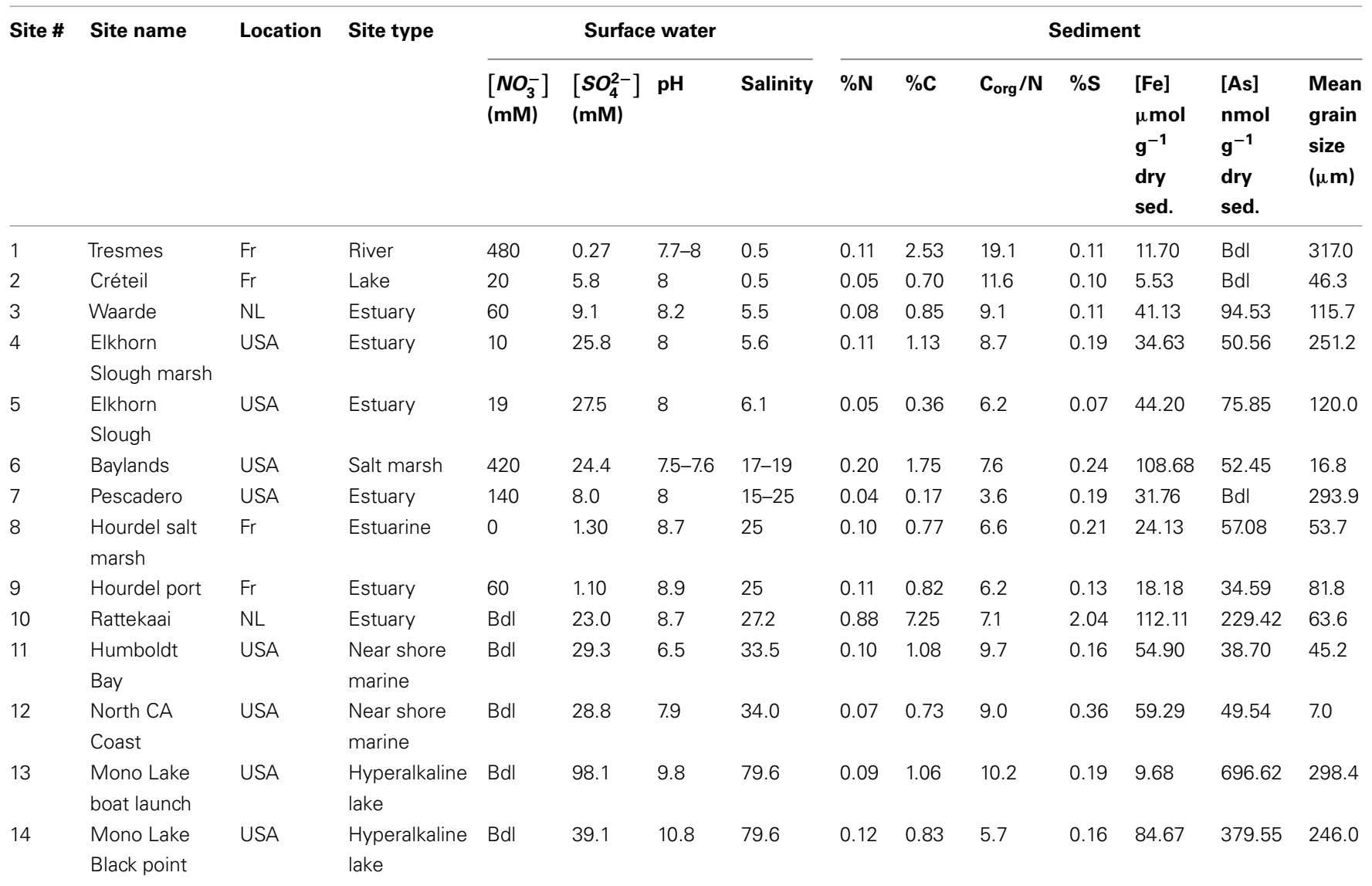

Bdl, below detection limit.

The detection limit for nitrate is $5 \mu \mathrm{M}$.

output samples were collected in tubes pre-filled with $2 \mathrm{~mL}$ of sulfide trap solution ( $1 \%$ zinc acetate) at 4 -h intervals using a fraction collector. Input solutions consisted of demineralized water containing $\mathrm{NO}_{3}^{-}$( $5 \mathrm{mM}$, supplied as $\left.\mathrm{NaNO}_{3}\right)$ or $\mathrm{SO}_{4}^{2-}(1.5 \mathrm{mM}$, supplied as $\mathrm{Na}_{2} \mathrm{SO}_{4}$ ) or both supplied simultaneously, $\mathrm{NaCl}$ at varying concentrations (see below), and for the Mono Lake sediments, also $\mathrm{Na}_{2} \mathrm{CO}_{3}(0.047 \mathrm{M})$ and $\mathrm{NaHCO}_{3}\left(0.28 \mathrm{M}\right.$; see below). $\mathrm{NO}_{3}^{-}$and $\mathrm{SO}_{4}^{2-}$ sulfate inflow concentrations have been chosen well above the half saturation constant $\left(K_{\mathrm{m}}\right)$ for $\mathrm{NO}_{3}^{-}(0.2-0.8 \mathrm{mM})$ and sulfate $(0.16-0.37 \mathrm{mM})$ that were measured in surface sediments using similar FTR systems (Laverman et al., 2006; Pallud et al., 2007 ) so maximum potential rates $\left(R_{\max }\right)$ would be measured. The input solutions were sterilized, then made anoxic by boiling and purging with $\mathrm{O}_{2}$-free $\mathrm{N}_{2}$. The salinity of the inflow solutions was adjusted with $\mathrm{NaCl}$ to match the salinity measured at the site (see Table 1). In order to mimic ambient hyperalkaline conditions in Mono Lake, the inflow $\mathrm{pH}$ for these reactors was adjusted using $\mathrm{Na}_{2} \mathrm{CO}_{3}(0.047 \mathrm{M})$ and $\mathrm{NaHCO}_{3}(0.28 \mathrm{M})$. For each site, two sets of duplicate reactors were treated as follows: one set was supplied with $\mathrm{NO}_{3}^{-}$for days $1-3(\mathrm{~N} 1)$, then with $\mathrm{SO}_{4}^{2-}$ for days 4-6(S2), and finally with $\mathrm{NO}_{3}^{-}$and $\mathrm{SO}_{4}^{2-}$ simultaneously for days 7-9 (N1S2); a second set of duplicates was supplied with $\mathrm{SO}_{4}^{2-}$ for days 1-3 (S1), then with $\mathrm{NO}_{3}^{-}$for days 4-6 (N2), and finally with $\mathrm{NO}_{3}^{-}$and $\mathrm{SO}_{4}^{2-}$

\section{Table 2 | Nomenclature of treatment groups.}

\begin{tabular}{llll} 
Treatments & Nitrate only (N) & Sulfate only (S) & Nitrate + sulfate (NS) \\
\hline Nitrate first & N1 & S2 & N1S2 \\
Sulfate first & N2 & S1 & N2S1
\end{tabular}

simultaneously for days 7-9 (N2S1). We will use the notation $\mathrm{N}$ to include both $\mathrm{NO}_{3}^{-}$only treatments ( $\mathrm{N} 1$ and N2), the notation $\mathrm{S}$ to include both $\mathrm{SO}_{4}^{2-}$ only treatments ( $\mathrm{S} 1$ and $\mathrm{S} 2$ ), and the notation $\mathrm{NS}$ to include both $\mathrm{NO}_{3}^{-}+\mathrm{SO}_{4}^{2-}$ treatments (N1S2 and N2S1). A summary of the notation system can be found in Table 2 . All FTR experiments were run at a constant temperature of $21 \pm 2^{\circ} \mathrm{C}$ under anoxic conditions.

\section{POTENTIAL REACTION RATE CALCULATIONS}

For each of the N1, N2, S1, S2, N1S2, N2S1 steps, potential steady-state reaction rates were calculated. Nitrate reduction rates (NRR), nitrite production rates (NiPR), ammonium production rate (APR), and sulfate production rates (SPR) were calculated for $\mathrm{N} 1$ and N2. Sulfate reduction rate (SRR), and APR were calculated for S1 and S2. Finally, NRR, NiPR, SRR, and APR were calculated for N1S2 and N2S1. Rates were determined by multiplying the 
flow rate $(Q)$ by the concentration difference between the input and output solutions normalized per volume of sediment for time intervals during which the outflow concentrations of the externally supplied electron acceptors $\left(\mathrm{NO}_{3}^{-}, \mathrm{SO}_{4}^{2-}\right.$ or both) remained constant (Laverman et al., 2006; Pallud et al., 2007), which typically happened after 10-24 h. Rates are expressed throughout in nanomolar analyte per cubic centimeter wet sediment per hour.

\section{STATISTICAL ANALYSIS}

MATLAB 9.0 was used to compute descriptive statistics and generate box plots of variables. Since the data were skewed, variables were log transformed before correlations and regressions were calculated. Variables having zero values were expressed as log $($ variable +1$)$. Log transforms improved the symmetry of the distributions. Differences in reaction rates across treatment types were tested with one way repeated measures ANOVA.

A principal component analysis (PCA) was conducted on the environmental variables and biogeochemical reaction rates, respectively. A multivariate analysis was conducted to analyze the relationships between explanatory variables (i.e., environmental variables) and response variables (i.e., biogeochemical reaction rates). The first step is to use detrended correspondence analyses (DCA) to obtain the gradient length of response variables. The linear model redundancy analysis (RDA) was suggested by the small gradient lengths ( $<1.5 \mathrm{SD}$ ). Stepwise RDA (Canoco Version 4.53; Wageningen, the Netherlands) was selected to study the effects of environmental variables on sediment biogeochemical reaction rates. RDA is a type of direct gradient analysis (Vandenwollenberg, 1977) that summarizes all the variance of response variables which is related to the explanatory variables and, at the same time, provides a synthetic and simple interpretation of the relationships between response and explanatory variables. Significant predictors were chosen using Canoco's forward selection procedure in the order of greatest additional contribution to the explained variance, but only if their addition did not cause any variation inflation factor to exceed 3.0. Statistical significance of variation components were tested with Monte Carlo Permutation tests (104 unrestricted permutations) on the trace statistic (Terbraak and Verdonschot, 1995). In the RDA triplot, the correlation between environmental variables and biogeochemical reaction rates is given by the cosine of the angle between the two vectors. Vectors pointing in roughly the same direction indicate a positive correlation, vectors crossing at right angles indicate a near zero correlation, while vectors pointing in opposite direction show a high negative correlation.

\section{RESULTS}

\section{WATER AND SEDIMENT CHARACTERISTICS}

Physical and chemical characteristics of the sediment and water column from the 14 study sites are summarized in Table 1. The overlying water $\mathrm{pH}$ and salinity values ranged from 6.5 to 10.8 and from 0.5 to 79.6 , respectively. The $\mathrm{C}_{\text {org }}: \mathrm{N}$ ratio ranged from 3.6 to 19.1 . The highest values (11.6 and 19.1) were observed in the freshwater sediments. The sediment $\mathrm{S}$ and Fe content ranged from 0.07 to $2.04 \%$ and from 5.53 to $112.11 \mu \mathrm{molg}^{-1}$ dry sediment, respectively, with the lowest values measured in the freshwater sediments. Sediment As content varied from below detection limit (bdl) to $696.62 \mathrm{nmol} \mathrm{g}^{-1}$ dry sediment and the lowest sediment As content were observed in the freshwater sediments.
The results of the PCA of the environmental variables revealed two main axes that explain most of the variation in all water and sediment characteristics (Figure 1). The first two principal components (PCs) explained 32 and $20 \%$ respectively of the total variance in the data. Correlations can be estimated by perpendicularly projecting the arrow tips of the other variables onto a particular variable arrow. The first component was mainly related to salinity, $\mathrm{SO}_{4}^{2-}$, and $\mathrm{NO}_{3}^{-}$concentration in the overlying water and sediment As content. The second PC was associated with sediment grain size and, to a lesser extent, with sediment total Fe content. Sediment total Fe content tended to increase with decreasing grain size. Coarse-grained sediments were generally poor in total Fe. In addition, sediment Fe content correlated positively with sediment $\mathrm{S}$ contents. The Fe and sulfur contents were negatively correlated to the $\mathrm{C}_{\text {org }}: \mathrm{N}$ ratio. The highest measured sediment $\mathrm{N}$ contents were associated with the highest measured Fe and/or $\mathrm{S}$ content. In general, sample sites were heterogeneously distributed around the origin of the coordinate system. On the basis of the distribution of sample PC scores on the PC1 and PC2 axes, several distinct sectors can be described: (1) the two hypersaline Mono lake sites (\#13 and 14) characterized by high $\mathrm{pH}$, salinity, $S_{4}^{2-}$ in overlying water and sediment As content; (2) the river sediment site at Tresmes (\#1) characterized by the highest $\mathrm{NO}_{3}^{-}$in overlying water and the highest $\mathrm{C}_{\mathrm{org}}: \mathrm{N}$ ratio; (3) the salt marsh estuarine site Rattekaai (\#10) characterized by high sediment $\mathrm{S}$ and Fe content; (4) the salt marsh site and two near coast marine sites (\#6, 11, and 12) characterized by fine texture and high sediment $\mathrm{Fe}$ content. The rest of the sample sites were within these extreme sectors.

\section{BIOGEOCHEMICAL REACTION RATES OF N AND S CYCLES}

The PCA of the reaction rates showed two main axes that explain most of the variation in all reaction rates (Figure 2). Note that all reaction rates reported in this study are maximum potential rates

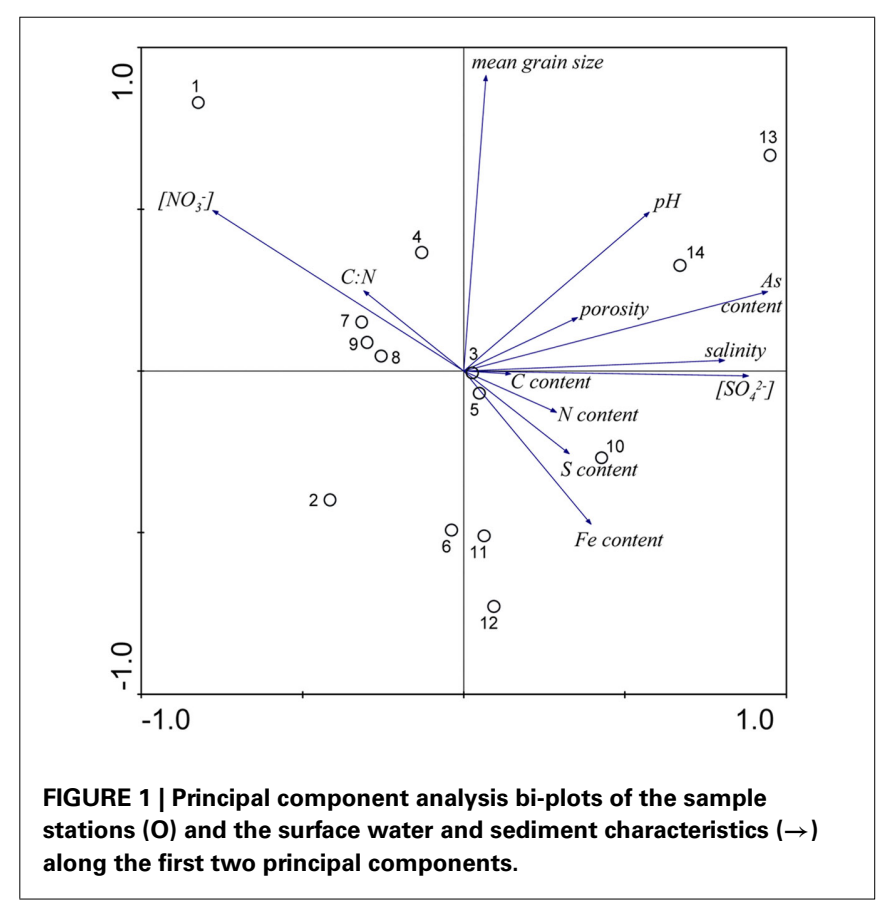




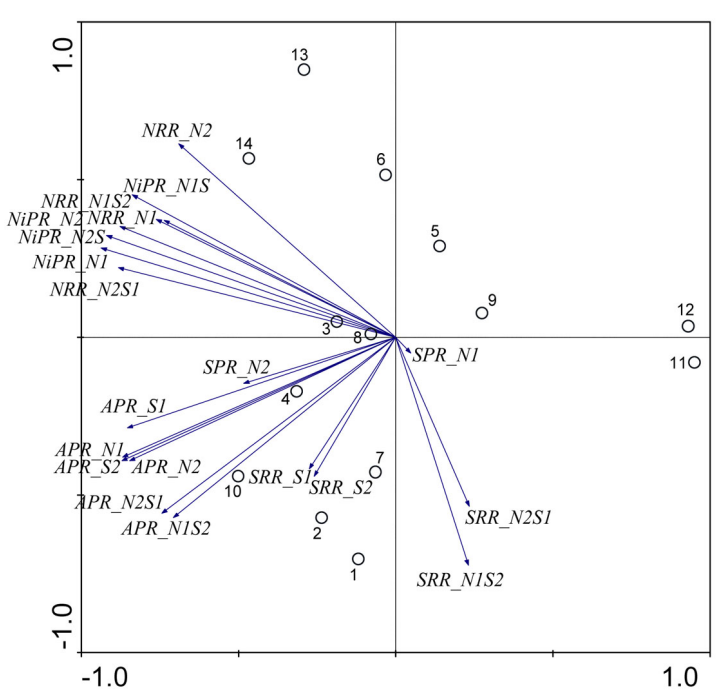

FIGURE 2 | Principal component analysis bi-plots of the sample stations $(0)$ and the potential reaction rates $(\rightarrow)$ along the first two principal components.

rather than field observed actual rates. The first two PCs explained 58 and $26 \%$ respectively of the total variance in the data. The first axis is related to NRR, NiPR, APR, and SPR. The second axis is defined mainly by SRR. NiRR increased with increasing NRR. Furthermore, NRR and APR for N treatments (i.e., N1 and N2) correlated strongly with those for NS treatments (i.e., N1S2 and $\mathrm{N} 2 \mathrm{~S} 1$ ). In contrast, there was no significant correlation between SRR for S treatment (i.e., S1 and S2) and SRR for NS treatments (i.e., N2S1 and N1S2). Several distinct sectors can be distinguished in all sediment sites based on the PC scores distribution: (1) the two hypersaline Mono Lake sites (\#13 and 14) characterized by high NRR and NiPR, and low SRR in the presence of $\mathrm{NO}_{3}^{-} ;(2)$ the river sediment site at Tresmes $(\# 1)$ and the freshwater lake site at Créteil (\#2) characterized by the highest SRR; (3) the estuarine site Rattekaai (\#10) characterized by the highest APR; (4) the two near coast marine sites (\#11 and 12) characterized by the lowest NRR and APR.

Nitrate reduction rates were highly variable within a given treatment [coefficient of variance (CV) ranged from 39 to $64 \%$, Figure 3]. There was no significant difference for the $\operatorname{NRR}(p=0.5$, repeated measures ANOVA) among the four treatment groups (i.e., N1, N2, N1S2, N2S1). The variances of NRR for N treatments were slightly larger than those for NS treatments.

Sulfate reduction rates varied greatly within a treatment $(\mathrm{CV}$ ranged from 46 to $94 \%$, Figure 4). The simultaneous application of $\mathrm{NO}_{3}^{-}$and $\mathrm{SO}_{4}^{2-}$ (NS) resulted in lower SRR than did a single application of $S_{4}^{2-}(\mathrm{S})$ ( $p=0.03$, repeated measures ANOVA). Note that the SRR here represented an apparent or net $\mathrm{SO}_{4}^{2-}$ removal after subtracting $\mathrm{SO}_{4}^{2-}$ produced by sulfide oxidation. By adding the SPR for the $\mathrm{N}$ treatments to the net SRR, we obtain estimates of the gross SRR (i.e., corrected SRR). Interestingly, there was no significant difference in the gross SRR between the $S$ and NS treatments ( $p=0.64$, repeated measures ANOVA). Additionally,

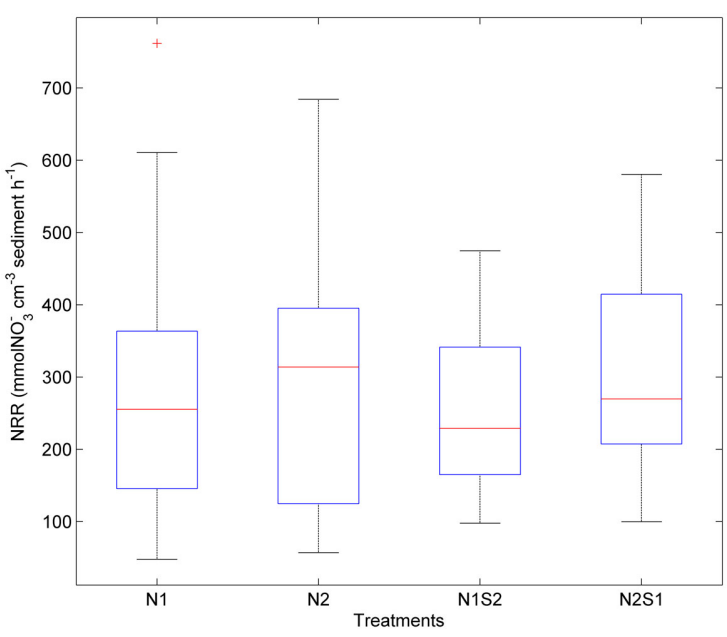

FIGURE 3 | Box plots of nitrate reduction rates (NRR) across all sites for the nitrate only treatments (N1 if nitrate first, N2 if sulfate first) and nitrate + sulfate treatments (N1S2 if nitrate first, N2S1 if sulfate first). Boxes encompass the upper and lower quartiles, while the line indicates the median. Asterisks are outliers.

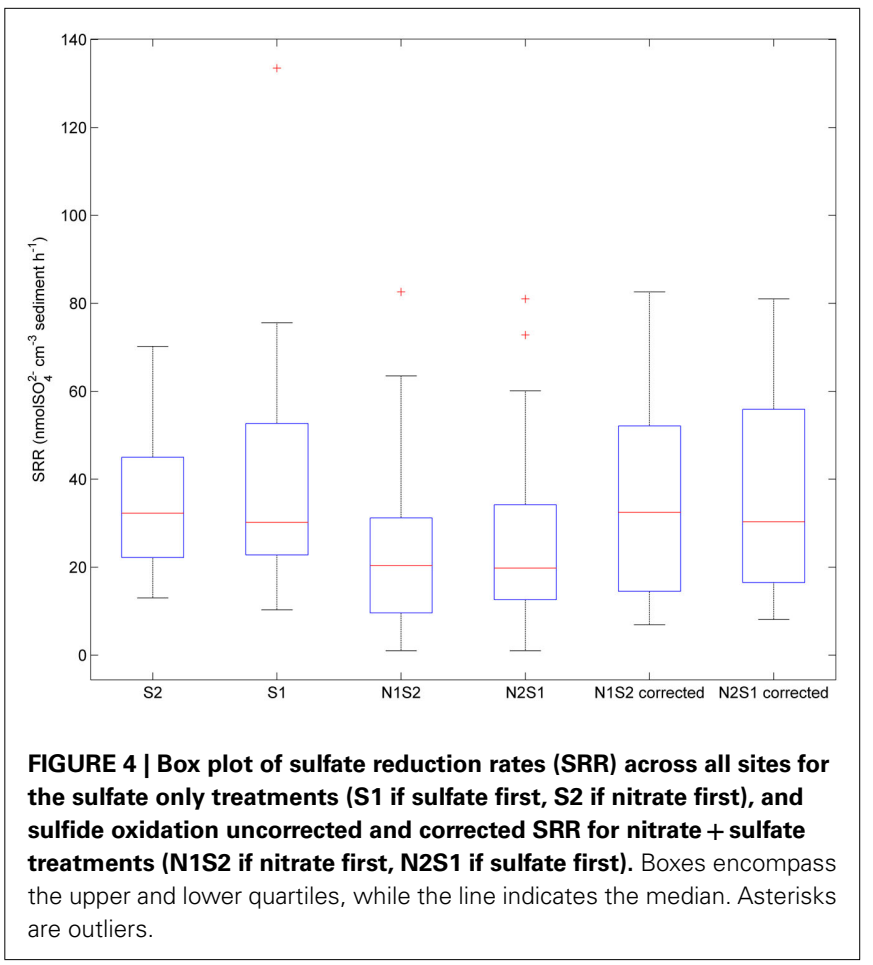

the average NRR was almost an order of magnitude higher than the average SRR.

The largest within-treatment variance was observed in APR (CV ranged from 77 to $149 \%$, Figure 5). APR did not vary greatly with treatments ( $p=0.3$, repeated measures ANOVA). However, the NS treatments had a greater variation of APR than the N or $S$ treatment. The extremely high APR values indicated by the three outliers were all from the Rattekaai site. 


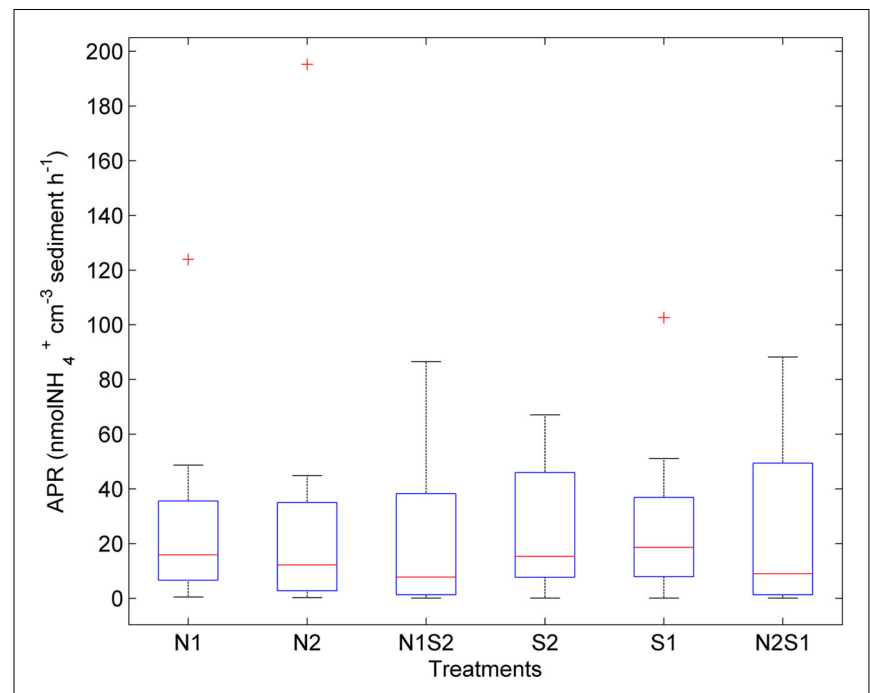

FIGURE 5 | Box plot of ammonium production rates (APR) across all for the nitrate only treatments (N1 of nitrate first, N2 if sulfate first), sulfate only treatments (S1 of sulfate first, $\mathbf{S 2}$ if nitrate first), and nitrate + sulfate treatments (N1S2 of nitrate first, N2S1 if sulfate first). Boxes encompass the upper and lower quartiles, while the line indicates the median. Asterisks are outliers.

\section{ENVIRONMENTAL CONTROLS ON BIOGEOCHEMICAL REACTION RATES}

Relationships between $\mathrm{N}$ and $\mathrm{S}$ biogeochemical reaction rates and the environmental variables measured were examined by RDA using the potential reaction rates measured on intact sediment slices as response variables for both separate and simultaneous addition of $\mathrm{NO}_{3}^{-}$and $\mathrm{SO}_{4}^{2-}$ (see Flow Through Reactor Experiments and Potential Reaction Rate Calculations) and the environmental variables listed in Table $\mathbf{1}$ as explanatory variables. The relative importance of various environmental factors is shown in Table 3. The single variable that explained the greatest percentage of variability in sediment biogeochemical reaction rates was the $\mathrm{pH}$ (lambda, the percentage of the variability explained by a single variable, is 0.24 ), followed by sediment As content, grain size, and $\mathrm{N}$ content that explained 21,17 , and $13 \%$ of the variability, respectively. After stepwise forward selection by RDA, three variables, namely $\mathrm{pH}$, salinity, and $\mathrm{N}$ content, that had a significant effect on the reaction rates in the sediments were retained ( $p<0.05$ tested by Monte Carlo permutation, Table 3). The $\mathrm{pH}$, salinity, and sediment $\mathrm{N}$ content describe the most variance (54\%) in the set of response variables that included all reaction rates. Exploratory RDA indicated that the $\mathrm{pH}$ of overlying water had the largest effect (lambda $\mathrm{A}$, the additional percentage of variability explained by a variable after the forward selection, is 0.24 , Table 3) for the $\mathrm{N}$ and $\mathrm{S}$ reaction rates. Salinity and sediment $\mathrm{N}$ content, as strong indicators of freshwater-marine ecosystem gradients, added an additional 18 and 12\% to the total explained variance.

Redundancy analysis results are visualized in triplot ordination diagrams. Figure 6 shows the ordination diagram derived from running an RDA using the reaction rates measured when only one
Table 3 | Summary of 12 environmental variables by their effects on sediment biogeochemical reaction rates.

\begin{tabular}{lllll}
\hline \multirow{2}{*}{ Variable } & Marginal effects & \multicolumn{3}{c}{ Conditional effects } \\
\cline { 3 - 5 } & Lambda 1 $^{\mathbf{1}}$ & Lambda A & $\boldsymbol{p}$ & $\boldsymbol{F}$ \\
\hline $\boldsymbol{p H}$ & 0.24 & 0.24 & $\mathbf{0 . 0 2}$ & 3.85 \\
$\mathrm{As}$ & 0.21 & 0.04 & 0.328 & 1.33 \\
$\mathrm{Grain}$ size & 0.17 & 0.06 & 0.158 & 1.57 \\
\% $N$ & 0.13 & 0.12 & $\mathbf{0 . 0 4}$ & 2.63 \\
{$\left[\mathrm{SO}_{4}^{2-}\right]$} & 0.12 & 0.09 & 0.09 & 2.12 \\
$\mathbf{S a l i n i t y}$ & 0.12 & 0.18 & $\mathbf{0 . 0 0 6}$ & 3.34 \\
$\% \mathrm{C}$ & 0.11 & 0.02 & 0.788 & 0.29 \\
$\% \mathrm{~S}$ & 0.09 & 0.03 & 0.35 & 1.23 \\
{$\left[\mathrm{NO}_{3}^{-}\right]$} & 0.07 & 0.04 & 0.304 & 1.23 \\
Fe & 0.06 & 0.04 & 0.4 & 1.04 \\
Porosity & 0.04 & 0.04 & 0.336 & 1.14 \\
$\mathrm{C}_{\text {org }}: \mathrm{N}$ & 0.04 & 0.06 & 0.172 & 1.72 \\
\hline
\end{tabular}

'Lambda 1 indicates the percentage of the variability in the sediment biogeochemical reaction rates explained by a single variable.

${ }^{2}$ Lambda $A$ indicates the percentage of the variability explained by a variable after the forward selection starting from the best variable (marginal effects).

Each subsequent variable is ranked on the basis of the fit that the variable gives in conjunction with the variables already selected (conditional effects). $p$ and $F$ values indicate the level of significance of each variable obtained by Monte Carlo permutations under the null model with 499 random permutations. The significant environmental variables were marked in italic bold.

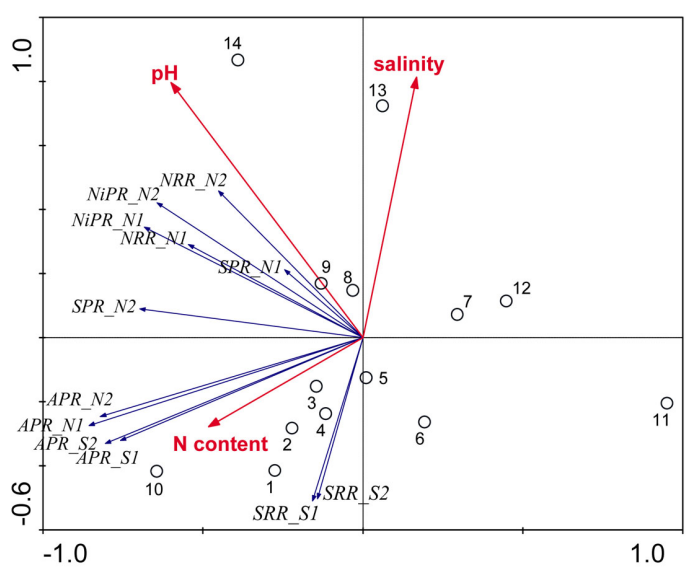

FIGURE 6 | Ordination triplots of first two axes (RDA1 and RDA2) generated from redundancy analysis using reaction rates (NRR, SRR, APR, NiPR, and SPR) measured when only one electron acceptor was added (treatments $\mathbf{N}$ and $\mathbf{S}$ ). Response variables (red vectors) include the combination of response variables (NRR and SRR). Explanatory variables (blue vectors) entered into the models were selected stepwise by Monte Carlo permutation test. Site numbers are located according to their ordination sample scores. Transform: response variable via log $10(x+1)$, and explanatory variables via square root. Vectors pointing in the same direction indicate a positive correlation, vectors crossing at right angles indicate a near zero correlation, while vectors pointing in opposite direction show a high negative correlation. 
electron acceptor was added (treatments $\mathrm{N}$ and $\mathrm{S}$ ). The first axis (horizontal) displayed a gradient of APR, and to a lesser extent, of SPR, NRR, and NiRR. The second axis (vertical) represented SRR, which were negatively correlated with salinity of the overlying water. In addition, the $\mathrm{pH}$ vector points in the same direction as the NRR and NiPR vectors indicating a significant positive correlation between $\mathrm{pH}$ and NRR and NiPR. pH explained 23\% of total variance, followed by salinity that contributed an additional 23\% and by sediment $\mathrm{N}$ content that explained an additional $15 \%$ of the total variance in reaction rates. The sites $1-5,8$, and 13 followed the salinity gradient strongly, while the sites $1-5,7$, and 12 were predominantly affected by the gradient of sediment $\mathrm{N}$ content. Finally, the variations associated with sites 5, 6, 8, 9, and 14 were mainly attributed to the variations in $\mathrm{pH}$.

An ordination diagram derived from running an RDA using the reaction rates measured for the NS treatments is shown in Figure 7. Again, $\mathrm{pH}$ and salinity are the two most dominant environmental variables that explained 30 and $17 \%$ of the total variance in reaction rates, respectively. The first RDA axis (horizontal) increased with decreasing $\mathrm{pH}$ and the second RDA axis (vertical) increased with salinity. The vectors of NRR and NiPR loaded negatively on the first axis, and pointed in a same direction as $\mathrm{pH}$, indicating a positive relationship with this explanatory variable. On the other hand, the vectors of SRR pointed roughly in a direction opposite to the salinity vectors, suggesting an inverse relationship between

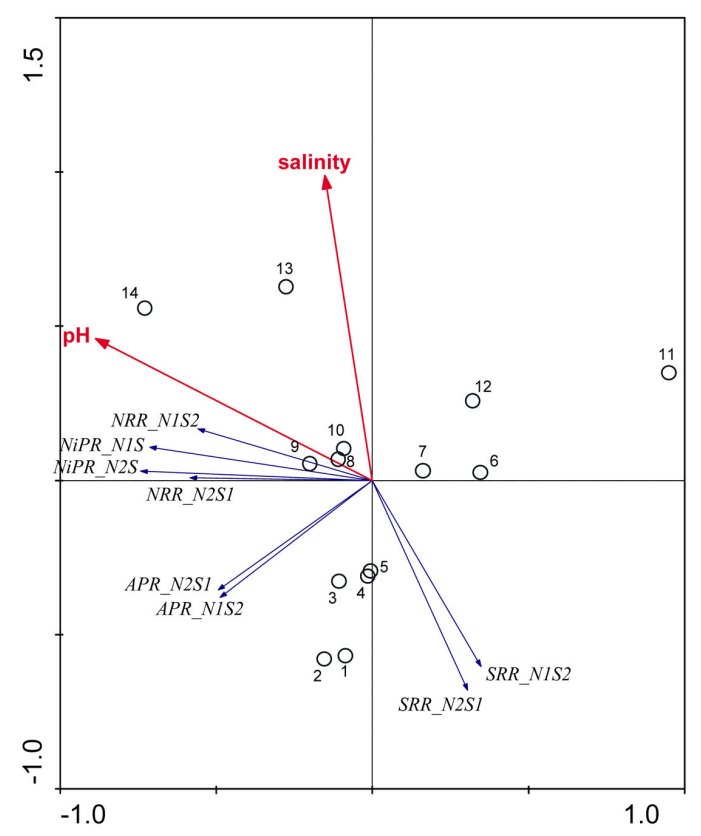

FIGURE 7 | Ordination triplots of first two axes (RDA1 and RDA2) generated from redundancy analysis using reaction rates (NRR, SRR, APR, and NiPR) measured when the two electron acceptors were added simultaneously (treatments NS). Response variables (red vectors) include the combination of response variables (NRR and SRR). Explanatory variables (blue vectors) entered into the models were selected stepwise by Monte Carlo permutation test. Site numbers are located according to their ordination sample scores. Transform: Response variable via log $10(x+1)$, and explanatory variables via square root. these variables. Contrary to the RCA results for reaction rates measured when only one TEA is present ( $\mathrm{N}$ and $\mathrm{S}$ treatments, Figure 6), sediment $\mathrm{N}$ content was not selected as a significant environmental factor on the reaction rates for the NS treatments.

To study the effect of environmental factors on the relative differences in NRR and SRR measured for separate (N or S) and simultaneous (NS) additions of $\mathrm{NO}_{3}^{-}$and $\mathrm{SO}_{4}^{2-}$, we derived a new set of response variables named Ratio_NRR and Ratio_SR, defined as the ratio of NRR and SRR measured in NS treatment compared to NRR and SRR measured for $\mathrm{N}$ and $\mathrm{S}$ treatment, respectively. These ratios indicate either an increase or a decrease in NRR or SRR when both TEAs are added compared to the supply of only one TEA. Stepwise RDA analysis (Figure 8) showed that the sediment As content (28\%), Fe content (17\%), and $\mathrm{C}_{\text {org }}: \mathrm{N}(14 \%)$ accounted for $59 \%$ of the total variance of the differences in NRR and SRR between separated or simultaneous addition of TEAs.

\section{DISCUSSION ENVIRONMENTAL CONTROLS ON POTENTIAL BIOGEOCHEMICAL REACTION RATES}

The PCA and RDA results revealed three dominant gradients in the variations in the sediment potential biogeochemical reaction rates. Gradient (1) is characterized by variations in the NRR, NiPR, and SPR, which were closely correlated with the overlying water $\mathrm{pH}$. Gradient (2) is characterized by variations in the APR, which were mainly controlled by the sediment $N$ content. Gradient (3) is characterized by variations in the SRR, which were correlated with the overlying water salinity.

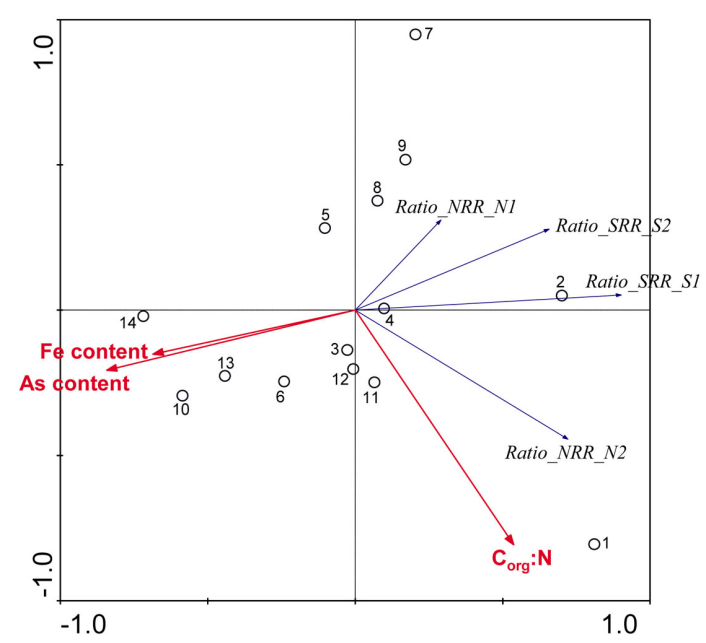

FIGURE 8 | Ordination triplots of first two axes (RDA1 and RDA2) generated from redundancy analysis using the ratio in NRR and SRR measured for separate ( $N$ or $S$ ) and simultaneous (NS) additions of nitrate and sulfate (RATIO_NRR and RATIO_SRR). Response variables (red vectors) include the combination of response variables. Explanatory variables (blue vectors) entered into the models were selected stepwise by Monte Carlo permutation test. All variables showed significant correlations with the canonical axes. Site numbers are located according to their ordination sample scores. Transform: response variable via log $10(x+1)$, and explanatory variables via square root. 
The RDA analysis suggested a significant positive relationship between in situ water $\mathrm{pH}$ and NRR and NiRR, which is in agreement with previous findings. Song et al. (2011) found a correlation between potential denitrification rates and the $\mathrm{pH}$ of the overlying water in constructed wetlands. In fact, several studies have shown that acidic conditions may reduce or even completely inhibit the nitrate reduction process in aquatic sediments (Knowles, 1982). In the present study, the in situ $\mathrm{pH}$ of overlying water is mostly slightly alkaline except for a slightly acidic $\mathrm{pH}$ of 6.5 at the near shore marine site, and for a hyperalkaline $\mathrm{pH}$ at the two Mono lake sites. Glass and Silverstein (1998) found that NRRs as well as the nitrate to nitrite ratios increased with above-neutral $\mathrm{pH}$ in activated sludge of a synthetic wastewater containing high nitrate concentration. Similar results were obtained in laboratory batch experiments by Zhang et al. (2009) showing increased nitrite accumulation with increasing $\mathrm{pH}$. Nitrite accumulation associated with nitrate reduction with increasing $\mathrm{pH}$ might be attributed to inhibition of nitrite reductase at high pH (Zhang et al., 2009).

Furthermore, our results suggest a positive correlation between APR and the sediment $\mathrm{N}$ pool. Sediment $\mathrm{N}$ can originate from various sources such as phytoplankton, benthic algae, and littoral deposition. As a result, littoral sediments are usually associated with high $\mathrm{N}$ content. In this study, the highest APR corresponded to the $\mathrm{N}$ rich sediment at the Rattekaai site, whereas the lowest APRs were found at two deep non-littoral marine sediments (\#11 and \#12). High N content sediments might lead to high APR through intensive anaerobic organic matter degradation and consequent nitrogen mineralization. Previous studies also observed increasing $\mathrm{NH}_{4}^{+}$production with decreasing $\mathrm{C}_{\mathrm{org}}: \mathrm{N}$ ratio (Blackburn and Henriksen, 1983). Under anoxic conditions, another $\mathrm{NH}_{4}^{+}$source is dissimilatory nitrate reduction to ammonium (DNRA). Our results, however, did not confirm that DNRA is significant. In fact, if DNRA was a major source of $\mathrm{NH}_{4}^{+}$, higher APR would be observed in the $\mathrm{N}$ only treatments than in the $\mathrm{S}$ only treatments. However, we did not find any significant difference in APR between these two treatments.

Finally, a freshwater to saline water gradient, represented by salinity in overlying water explained a large portion of variance of the sediment SRR. In situ salinity showed an inverse relationship with SRR. Under in situ conditions, SRR in most freshwater systems are usually very low and considerably lower than in most marine systems (Capone and Kiene, 1988) due to the limited $\mathrm{SO}_{4}^{2-}$ present in the overlying water. Despite these low in situ rates and activities, sulfate reducers have shown to be present and diverse in freshwater sediments (Kondo et al., 2007; Miletto et al., 2008), and with high potential activities (this study, Pallud and Van Cappellen, 2006; Kondo et al., 2007), most likely due to their metabolic diversity (Muyzer and Stams, 2008). In addition, in hypersaline anaerobic environments, the significant energetic requirements associated with halophilism may preclude the existence of microbial groups that obtain little energy from dissimilatory processes, including sulfate reduction (Oren, 2011). This could explain why the lowest SRR were observed in the two hypersaline sites.

We found both similarities and differences in the sets of environmental factors that explain the variance in the sediment $\mathrm{N}$ and $\mathrm{S}$ potential reaction rates between separate and simultaneous addition of $\mathrm{NO}_{3}^{-}$and $\mathrm{SO}_{4}^{2-}$. Both treatments suggest that $\mathrm{pH}$ and salinity are the two most important predictors of variability of sediment $\mathrm{N}$ and $\mathrm{S}$ reaction rates. However, when $\mathrm{NO}_{3}^{-}$and $\mathrm{SO}_{4}^{2-}$ were added separately, the APR were also significantly affected by sediment $\mathrm{N}$ content, but not when $\mathrm{NO}_{3}^{-}$and $\mathrm{SO}_{4}^{2-}$ were added concomitantly. This indicates that other process(es) than anaerobic organic nitrogen mineralization might contribute to $\mathrm{NH}_{4}^{+}$ production when $\mathrm{N}$ and $\mathrm{S}$ were added together.

Distinct biogeochemical processes in response to separate and simultaneous addition of $\mathrm{NO}_{3}^{-}$and $\mathrm{SO}_{4}^{2-}$ can also be suggested by the comparison of NRR and SRR between separate addition and simultaneous addition of $\mathrm{NO}_{3}^{-}$and $\mathrm{SO}_{4}^{2-}$. Sediment As, $\mathrm{C}_{\mathrm{org}}$ : N ratio, and $\mathrm{Fe}$ content were the main factors that explained the variation of the NRR and SRR changes. The coupled sediment $S$, As, and Fe cycles, probably through the reactions listed in Table 4, explained the lower SRR in sediments when $\mathrm{NO}_{3}^{-}$and $\mathrm{SO}_{4}^{2-}$ were present. On the other hand, the quality of sediment organic matter, indicated by $\mathrm{C}_{\mathrm{org}}: \mathrm{N}$ ratio, might account for the majority of variance in the NRR changes.

\section{EFFECTS OF ALTERNATIVE TEAs ON POTENTIAL NITRATE AND SULFATE REDUCTION RATES}

The lack of correlation of SRR between S only and NS treatments suggested that distinct processes must be involved in $\mathrm{SO}_{4}^{2-}$ reduction. The observation that the presence of $\mathrm{NO}_{3}^{-}$results in lower overall SRR than when $\mathrm{SO}_{4}^{2-}$ is added alone suggests that $\mathrm{SO}_{4}^{2-}$ reduction was inhibited by the presence of $\mathrm{NO}_{3}^{-}$and/or that, $\mathrm{SO}_{4}^{2-}$ was produced by sulfide oxidation (reaction 1 in Table 4). The gross SRR in the NS treatments was calculated by adding the SPR measured in the $\mathrm{N}$ treatments to the net SRR measured for the NS treatments. The corrected SRR for the NS treatments were not significantly different than for the $\mathrm{S}$ treatments. This confirms that the lower SRR measured when $\mathrm{NO}_{3}^{-}$and $\mathrm{SO}_{4}^{2-}$ were added together are most likely due to the $\mathrm{SO}_{4}^{2-}$ produced from sulfide oxidation linked to $\mathrm{NO}_{3}^{-}$reduction. Therefore, not only do we observe active $\mathrm{SO}_{4}^{2-}$ reduction when $\mathrm{NO}_{3}^{-}$is present but we also conclude that overall there is negligible inhibition of $\mathrm{SO}_{4}^{2-}$ reduction by the presence of $\mathrm{NO}_{3}^{-}$. This contrasts with the current consensus that $\mathrm{SO}_{4}^{2-}$ reduction will be active only when $\mathrm{NO}_{3}^{-}$, a thermodynamically more favorable electron acceptor, is fully consumed (Froelich et al., 1979; Whitmire and Hamilton, 2005). However, it is supported by previous

Table 4 | Summary of stoichiometric reactions of sulfide oxidized by varying terminal electron acceptors.

\begin{tabular}{llc}
\hline TEA & Stoichiometric reactions & Number \\
\hline Nitrate & $5 \mathrm{HS}^{-}+8 \mathrm{NO}_{3}^{-}+3 \mathrm{H}^{+} \rightarrow 5 \mathrm{SO}_{4}^{2-}+4 \mathrm{~N}_{2}+4 \mathrm{H}_{2} \mathrm{O}$ & 1 \\
& $\mathrm{FeS}_{2}+14 \mathrm{NO}_{3}^{-}+4 \mathrm{H}^{+} \rightarrow 7 \mathrm{~N}_{2}+10 \mathrm{SO}_{4}^{2-}+$ & 2 \\
& $5 \mathrm{Fe}^{2+}+2 \mathrm{H}_{2} \mathrm{O}$ & \\
& $5 \mathrm{Fe}^{2+}+\mathrm{NO}_{3}^{-}+12 \mathrm{H}_{2} \mathrm{O} \rightarrow 5 \mathrm{Fe}(\mathrm{OH})_{3}+1 / 2 \mathrm{~N}_{2}+$ & 3 \\
& $9 \mathrm{H}^{+}$ & \\
& $\mathrm{FeS}_{2}+8 \mathrm{H}_{2} \mathrm{O}+14 \mathrm{Fe}^{3+} \rightarrow 2 \mathrm{SO}_{4}^{2-}+15 \mathrm{Fe}^{2+}+$ & 4 \\
Iron & $16 \mathrm{H}^{+}$ & \\
& $4 \mathrm{AsO}_{4}^{2-}+\mathrm{S}^{2-}+4 \mathrm{H}^{+} \rightarrow 4 \mathrm{H}_{2} \mathrm{AsO}_{3}^{-}+\mathrm{SO}_{4}^{2-}$ & 5 \\
Arsenic & $\mathrm{FeS}_{2}+7.5 \mathrm{MnO}_{2}+11 \mathrm{H}^{+} \rightarrow \mathrm{Fe}(\mathrm{OH})_{3}+2 \mathrm{SO}_{4}^{2-}+$ & 6 \\
Manganese & $7.5 \mathrm{Mn}{ }^{2+}+4 \mathrm{H}_{2} \mathrm{O}$ & \\
& $\mathrm{FeS}+1.5 \mathrm{MnO}_{2}+3 \mathrm{H}^{+} \rightarrow \mathrm{Fe}(\mathrm{OH})_{3}+\mathrm{S}^{0}+1.5 \mathrm{Mn}^{2+}$ & 7
\end{tabular}


observations that $\mathrm{SO}_{4}^{2-}$ was actively reduced by microorganisms in the presence of $\mathrm{NO}_{3}^{-}$(Dalsgaard and Bak, 1994). It is very well likely, considering the metabolic versatility of both the $\mathrm{SO}_{4}^{2-}$ and $\mathrm{NO}_{3}^{-}$-reducers, that active sulfate reduction in the presence of nitrate is due to the use of different electron donors by the two bacterial groups. In addition, the sediment matrix could provide a spatial separation of the different microbial groups resulting in coexistence instead of a competition between the two processes within these sediments. Whether spatial separation or the use of different carbon pools allows the coexistence of sulfate and nitrate reduction in these sediments is subject to ongoing work.

On the other hand, the presence of $\mathrm{SO}_{4}^{2-}$, and subsequently of sulfide produced as a result of $\mathrm{SO}_{4}^{2-}$ reduction, did not significantly affect NRR. The strong correlation between NRR measured for $\mathrm{N}$ only and for NS treatments suggested that same processes must be involved in $\mathrm{NO}_{3}^{-}$reduction. Sulfide has been shown to inhibit nitrate reduction in estuarine and coastal sediments (Senga et al., 2006; Aelion and Warttinger, 2009). However, a positive effect of sulfide addition on NRR has been found in oxidized and low organic matter sediments (Canfield et al., 2010). Recent work in a marine environment off the Chilean northern coast suggests that $\mathrm{NO}_{3}^{-}$reduction is enhanced by sulfide addition in ocean waters (Canfield et al., 2010). In our study, however, the amount of sulfide produced as a result of $\mathrm{SO}_{4}^{2-}$ reduction was too low to enhance or inhibit $\mathrm{NO}_{3}^{-}$removal. We estimated the fraction of $\mathrm{NO}_{3}^{-}$removal due to sulfide oxidation to $\mathrm{SO}_{4}^{2-}$ by multiplying the ratio of the measured SPR to NRR by 1.6, which is the molar ratio of $\mathrm{NO}_{3}^{-}$ reduced to $\mathrm{SO}_{4}^{2-}$ produced as shown in Equation 1 (Table 4). In our survey, $\mathrm{NO}_{3}^{-}$mediated sulfide oxidation accounts for a small portion $(\sim 9 \%)$ of total $\mathrm{NO}_{3}^{-}$reduction on average, implying that this process did not affect overall $\mathrm{NO}_{3}^{-}$reduction significantly. Furthermore, the observation that $\mathrm{SO}_{4}^{2-}$ was produced in the absence of $\mathrm{SO}_{4}^{2-}$ addition suggests that sediment $\mathrm{S}$ content is the main source of sulfide in our systems, probably from sediment bound sulfide rather than produced by $\mathrm{SO}_{4}^{2-}$ reduction. However, the effect of $\mathrm{SO}_{4}^{2-}$ reduction as a sulfide source cannot be underestimated due to the fact that sediment sulfide is ultimately regenerated from $\mathrm{SO}_{4}^{2-}$ reduction.

In addition to $\mathrm{NO}_{3}^{-}$, oxidized metal(loid) species, such as $\mathrm{Fe}$, $\mathrm{Mn}$, and As, could be preferentially used over $\mathrm{SO}_{4}^{2-}$ by microorganisms as TEA for anaerobic respiration. For example, it has been shown that direct sulfide oxidation by $\mathrm{Fe}(\mathrm{III})$ might lead to $\mathrm{SO}_{4}^{2-}$ production (reaction 4, in Table 4; Holmer and Storkholm, 2001). In our study, SRR decreased in the NS treatments with increasing sediment As content suggesting that SRR might be inhibited by As, possibly by $\mathrm{As}(\mathrm{V})$ produced via $\mathrm{As}(\mathrm{III})$ oxidation coupled to $\mathrm{NO}_{3}$-reduction. Such an anoxic oxidation of As(III) linked to chemolithotrophic denitrification was shown to be feasible in continuous bioreactors (Sun et al., 2010). The oxidized As subsequently affect the sediment $\mathrm{S}$ cycle in two ways. First, $\mathrm{As}(\mathrm{V})$ and/or As(III) inhibit $\mathrm{SO}_{4}^{2-}$ reduction, presumably through a toxic effect (Dowdle et al., 1996). Second, $\mathrm{SO}_{4}^{2-}$ might be produced through As $(\mathrm{V})$-mediated sulfide oxidation (reaction 5 in Table 4). Recent studies (Hoeft et al., 2004; Oremland et al., 2005; Hollibaugh et al., 2006) found that sulfide oxidation coupled to As(V) reduction appears to proceed via a two electron transfer, resulting in the production of As(III) and of an intermediate $S$ compound such as thiosulfate that is subsequently disproportionated into sulfate. Oxidized Mn might also serve as electron acceptor to oxidize iron sulfide minerals (reactions 6 and 7 in Table 4). However, we did not measure sediment $\mathrm{Mn}$ content in our study and consequently cannot confirm the occurrence of Mn-mediated sulfide oxidation.

\section{ALTERNATIVE NITRATE REMOVAL PATHWAYS}

Our observation that in $70 \%$ of the studied sites $\mathrm{SO}_{4}^{2-}$ was produced when $\mathrm{NO}_{3}^{-}$was reduced suggested that $\mathrm{SO}_{4}^{2-}$ production was linked to $\mathrm{NO}_{3}^{-}$removal. The possibility of $\mathrm{NO}_{3}^{-}$reduction coupled to sulfide oxidation by sulfur-oxidizing bacteria is supported by research in both marine and freshwater ecosystems (Dannenberg et al., 1992; Fossing et al., 1995; Brunet and GarciaGil, 1996; Otte et al., 1999). On average, 9\% of the NRR can be accounted for by sulfide oxidation to sulfate in our studied sediments (Laverman et al., 2012), which is much lower than the range of $25-40 \%$ reported for freshwater ecosystems (Burgin and Hamilton, 2008). Note that these could be minimum estimates because of the possibility that some of the $\mathrm{S}$ oxidation does not proceed completely to $\mathrm{SO}_{4}^{2-}$.

We were not able to ascertain the ultimate fate of the added $\mathrm{NO}_{3}^{-}$(i.e., denitrification or DNRA) in our sediments. Inhibition of denitrification by the presence of free sulfide might favor the reduction of $\mathrm{NO}_{3}^{-}$to $\mathrm{NH}^{4+}$ rather than to $\mathrm{N}_{2} \mathrm{O}$ and $\mathrm{N}_{2}$ (Brunet and GarciaGil, 1996), though accumulation of $\mathrm{N}_{2} \mathrm{O}$ has also been observed (Senga et al., 2006). An increase in NRR due to DNRA coupled with $S$ oxidation would likely be accompanied by an increase in APR (Payne et al., 2009). However our results did not show significant increase in APR when $\mathrm{NO}_{3}^{-}$and $\mathrm{SO}_{4}^{2-}$ were added together, ruling this hypothesis out. On the other hand, metalbound sulfides (e.g., FeS) could potentially enhance denitrification to $\mathrm{N}_{2}$ (Brunet and GarciaGil, 1996). We consequently speculate that denitrification instead of DNRA is the major pathway of $\mathrm{NO}_{3}^{-}$ reduction that couples with metal-bound sulfide oxidation in the present study.

Our RDA results revealed that nitrate-mediated oxidation of iron sulfide (FeS) or Fe disulfide $\left(\mathrm{FeS}_{2}\right)$, rather than free sulfide, might account for $\mathrm{SO}_{4}^{2-}$ production (reactions 2 and 3 in Table 4). This is supported by the positive correlation between change of SRRs (NS vs. S) and sediment Fe contents in our RDA analysis. $\mathrm{FeS}$ and $\mathrm{FeS}_{2}$ are compounds resulting from the chemical precipitation of reduced $\mathrm{Fe}$ and sulfur, and are commonly found in sediments, such as those investigated in this study. The sediment $\mathrm{Fe}$ content correlated positively with sediment $\mathrm{S}$ contents in this study, which indicated that iron and sulfide could be present as iron sulfide minerals such as $\mathrm{FeS}$ and $\mathrm{FeS}_{2}$. The oxidation of iron disulfide coupled to $\mathrm{NO}_{3}^{-}$reduction produces $\mathrm{SO}_{4}^{2-}$ as end product (Brunet and GarciaGil, 1996). Under anoxic conditions FeS or $\mathrm{FeS}_{2}$ can be used as electron donors for denitrification by facultative anaerobic lithotrophs (Benz et al., 1998; Schwientek et al., 2008). Jorgensen et al. (2009) recently found that around 65$80 \%$ of the $\mathrm{NO}_{3}^{-}$reduction measured in a groundwater aquifer was coupled to the anoxic oxidation of pyrite by $\mathrm{NO}_{3}^{-}$, releasing $\mathrm{SO}_{4}^{2-}$. 


\section{CONCLUSION}

Our study shows that the effects of the presence of $\mathrm{NO}_{3}^{-}$and/or $\mathrm{SO}_{4}^{2-}$ on biogeochemical $\mathrm{N}$ and $\mathrm{S}$ cycles are complex, depending on various environmental factors. The environmental factors that explained the variability in the $\mathrm{N}$ and $\mathrm{S}$ biogeochemical reaction rates when $\mathrm{NO}_{3}^{-}$and $\mathrm{SO}_{4}^{2-}$ were present simultaneously were in situ water $\mathrm{pH}$ and salinity, whereas sediment $\mathrm{N}$ content, in situ water $\mathrm{pH}$ and salinity were the best explanatory variables when $\mathrm{NO}_{3}^{-}$and $\mathrm{SO}_{4}^{2-}$ were present separately. More specifically, potential NRR were positively correlated to in situ water $\mathrm{pH}$ and potential SRR were inversely correlated with salinity. Furthermore, the highest sediment As or Fe content was associated with the largest reduction in the potential SRR when $\mathrm{NO}_{3}^{-}$ or $\mathrm{SO}_{4}^{2-}$ were both present. Finally, our results indicate that the simultaneous presence of $\mathrm{NO}_{3}^{-}$and $\mathrm{SO}_{4}^{2-}$ led to sulfur oxidation coupled with $\mathrm{NO}_{3}^{-}$reduction and metal-bound S, instead of free sulfide produced by $\mathrm{SO}_{4}^{2-}$ reduction, was responsible for this $\mathrm{NO}_{3}^{-}$- mediated $\mathrm{S}$ oxidation.

Aquatic ecosystems are exposed to increasing $\mathrm{NO}_{3}^{-}$and $\mathrm{SO}_{4}^{2-}$ concentrations and intensified interactions between the $\mathrm{N}$ and $\mathrm{S}$ cycles. The sulfur induced nitrate reduction observed in this study implies that sediment $\mathrm{N}$ cycling is closely linked to the $\mathrm{S}$ cycling across a wide range of sediments. Increased $\mathrm{SO}_{4}^{2-}$ concentrations in freshwater ecosystems will lead to sulfide production in such

\section{REFERENCES}

Aelion, C. M., and Warttinger, U. (2009). Low sulfide concentrations affect nitrate transformations in freshwater and saline coastal retention pond sediments. Soil Biol. Biochem. 41, 735-741.

Benz, M., Brune, A., and Schink, B. (1998). Anaerobic and aerobic oxidation of ferrous iron at neutral $\mathrm{pH}$ by chemoheterotrophic nitratereducing bacteria. Arch. Microbiol. $169,159-165$.

Blackburn, T. H., and Henriksen, K. (1983). Nitrogen cycling in different types of sediments from danish waters. Limnol. Oceanogr. 28, 477-493.

Brettar, I., and Rheinheimer, G. (1991). Denitrification in the central balticevidence for $\mathrm{H} 2 \mathrm{~s}$-oxidation as motor of denitrification at the oxic-anoxic interface. Mar. Ecol. Prog. Ser. 77, 157-169.

Brunet, R. C., and GarciaGil, L. J. (1996). Sulfide-induced dissimilatory nitrate reduction to ammonia in anaerobic freshwater sediments. FEMS Microbiol. Ecol. 21, 131-138.

Burgin, A. J., and Hamilton, S. K. (2007). Have we overemphasized the role of denitrification in aquatic ecosystems? A review of nitrate removal pathways. Front. Ecol. Environ. 5, 89-96.
Burgin, A. J., and Hamilton, S. K. (2008). $\mathrm{NO}_{3}{ }^{-}$driven $\mathrm{SO}_{4}{ }^{2-}$ production in freshwater ecosystems: implications for $\mathrm{N}$ and S cycling. Ecosystems 11, 908-922.

Canfield, D. E., Stewart, F. J., Thamdrup, B., De Brabandere, L., Dalsgaard, T., Delong, E. F., Revsbech, N. P., and Ulloa, O. (2010). A cryptic sulfur cycle in oxygen-minimum-zone waters off the chilean coast. Science 330, 1375-1378.

Capone, D. G., and Kiene, R. P. (1988). Comparison of microbial dynamics in marine and fresh-water sediments - contrasts in anaerobic carbon catabolism. Limnol. Oceanogr. $33,725-749$.

Cornwell, J. C., Kemp, W. M., and Kana, T. M. (1999). Denitrification in coastal ecosystems: methods, environmental controls, and ecosystem level controls, a review. Aquatic Ecol. 33, 41-54.

Dalsgaard, T., and Bak, F. (1994). Nitrate reduction in a sulfate-reducing bacterium, desulfovibrio-desulfuricans, isolated from rice paddy soil - sulfide inhibition, kinetics, and regulation. Appl. Environ. Microbiol. 60, 291-297.

Dannenberg, S., Kroder, M., Dilling, W., and Cypionka, H. (1992). Oxidation of $\mathrm{H}-2$, organic-compounds and inorganic sulfur-compounds coupled to reduction of $\mathrm{O}-2$ or nitrate

ecosystems, where sulfide concentrations are usually low (Capone and Kiene, 1988). This sulfide can either be oxidized coupled to nitrate reduction as shown in this study, or serve as a sink for potentially toxic metals, such as As, $\mathrm{Cd}, \mathrm{Hg}$, and $\mathrm{Pb}$ (Moller et al., 2004). Increasing anthropogenic $\mathrm{NO}_{3}^{-}$input from acid deposition and agricultural runoff to ecosystems might affect the $\mathrm{S}$ cycle by stimulating anoxic iron sulfide oxidation in iron sulfide rich sediments. As observed in this study, the magnitude of the sulfide oxidation coupled to $\mathrm{NO}_{3}^{-}$reduction increases with increasing sediment As and $\mathrm{Fe}$ content, which means that saline sediments rich in metal (such as As and Fe) would be more strongly affected. Through the release of toxic metals by metal sulfide oxidation (Morse, 1994; Haaijer et al., 2007), this stimulation will have adverse effects on aquatic ecosystems. It is therefore crucial to better understand the coupling between the $\mathrm{N}$ and the $\mathrm{S}$ cycles given that $\mathrm{NO}_{3}^{-}$and $\mathrm{SO}_{4}^{2-}$ inputs to ecosystems are enhanced by anthropogenic activities, and are expected to increase in the future.

\section{ACKNOWLEDGMENTS}

C. Gu and C. Pallud are grateful to the Agricultural Experimental Station (AES) for funding the work done at UC Berkeley. The authors would also like to thank Jeffrey Abell for providing his data for the two near shore marine sites and Emmanuel Aubry for Fe and As analysis.

by sulfate-reducing bacteria. Arch. Microbiol. 158, 93-99.

Dowdle, P. R., Laverman, A. M., and Oremland, R. S. (1996). Bacterial dissimilatory reduction of $\operatorname{arsenic}(\mathrm{V})$ to $\operatorname{arsenic}(\mathrm{III})$ in anoxic sediments. Appl. Environ. Microbiol. 62, 1664-1669.

Duan, K., Thompson, L. G., Yao, T., Davis, M. E., and MosleyThompson, E. (2007). A 1000 year history of atmospheric sulfate concentrations in southern Asia as recorded by a Himalayan ice core. Geophys. Res. Lett. 34, L01810.

Engesgaard, P., and Kipp, K. L. (1992). A geochemical transport model for redox-controlled movement of mineral fronts in groundwater-flow systems - a case of nitrate removal by oxidation of pyrite. Water Resour. Res. 28, 2829-2843.

Ericson, J. P., Vorosmarty, C. J., Dingman, S. L., Ward, L. G., and Meybeck, M. (2006). Effective sea-level rise and deltas: causes of change and human dimension implications. Glob. Planet. Change 50, 63-82.

Fischer, H., Wagenbach, D., and Kipfstuhl, J. (1998). Sulfate and nitrate firn concentrations on the Greenland ice sheet -2 . Temporal anthropogenic deposition changes. J. Geophys. Res. 103, 21935-21942.

Fossing, H., Gallardo, V. A., Jørgensen, B. B., Hüttel, M., Nielsen, L. P.,
Schulz, H., Canfield, D. E., Forster, S., Glud, R. N., Gundersen, J. K., Küver, J., Ramsing, N. B., Teske, A., Thamdrup, B., and Ulloa, O. (1995). Concentration and transport of nitrate by the mat-forming sulfur bacterium Thioploca. Nature 374, 713-715.

Froelich, P. N., Klinkhammer, G. P., Bender, M. L., Luedtke, N. A., Heath, G. R., Cullen, D., Dauphin, P., Hammond, D., Hartman, B., and Maynard, V. (1979). Early oxidation of organic-matter in pelagic sediments of the eastern equatorial atlantic suboxic diagenesis. Geochim. Cosmochim. Acta 43, 1075-1090.

Galloway, J. N., Townsend, A. R., Erisman, J. W., Bekunda, M., Cai, Z., Freney, J. R., Martinelli, L. A., Seitzinger, S. P., and Sutton, M. A. (2008). Transformation of the nitrogen cycle: recent trends, questions, and potential solutions. Science 320, 889-892.

Garciagil, L. J., and Golterman, H. L. (1993). Kinetics of FeS-mediated denitrification in sediments from the Camargue (Rhone delta, southern France). FEMS Microbiol. Ecol. 13, 85-91.

Glass, C., and Silverstein, J. (1998). Denitrification kinetics of high nitrate concentration water: $\mathrm{pH}$ effect on inhibition and nitrite accumulation. Water Res. 32, 831-839. 
Haaijer, S. C. M., Lamers, L. P. M., Smolders, A. J. P., Jetten, M. S. M., and den Camp, H. J. M. O. (2007). Iron sulfide and pyrite as potential electron donors for microbial nitrate reduction in freshwater wetlands. Geomicrobiol. J. 24, 391-401.

Hoeft, S. E., Kulp, T. R., Stolz, J. F., Hollibaugh, J. T., and Oremland, R. S. (2004). Dissimilatory arsenate reduction with sulfide as electron donor: experiments with mono lake water and isolation of strain MLMS-1, a chemoautotrophic arsenate respirer. Appl. Environ. Microbiol. 70, 2741-2747.

Hollibaugh, J. T., Budinoff, C., Hollibaugh, R. A., Ransom, B., and Bano, N. (2006). Sulfide oxidation coupled to arsenate reduction by a diverse microbial community in a Soda Lake. Appl. Environ. Microbiol. 72, 2043-2049.

Holmer, M., and Storkholm, P. (2001). Sulphate reduction and sulphur cycling in lake sediments: a review. Freshw. Biol. 46, 431-451.

Howarth, R. W., Billen, G., Swaney, D., Townsend, A., Jaworski, N., Lajtha, K., Downing, J. A., Elmgren, R., Caraco, N., Jordan, T., Berendse, F., Freney, J., Kudeyarov, V., Murdoch, P., and Zhu, Z. L. (1996). Regional nitrogen budgets and riverine N\&P fluxes for the drainages to the North Atlantic Ocean: natural and human influences. Biogeochemistry 35, 75-139.

Jorgensen, C. J., Jacobsen, O. S., Elberling, B., and Aamand, J. (2009). Microbial oxidation of pyrite coupled to nitrate reduction in anoxic groundwater sediment. Environ. Sci. Technol. 43, 4851-4857.

Knowles, R. (1982). Denitrification. Microbiol. Rev. 46, 43-70.

Kondo, R., Purdy, K. J., Silva, S. D. Q., and Nedwell, D. B. (2007). Spatial dynamics of sulphate-reducing bacterial compositions in sediment along a salinity gradient in a UK estuary. Microbes Environ. 22, 11-19.

Laverman, A. M., Pallud, C., Abell, J., and Van Cappellen, P. (2012). Comparative survey of potential nitrate and sulfate reduction rates in aquatic sediments. Geochim. Cosmochim. Acta 77, 474-488.

Laverman, A. M., Van Cappellen, P., van Rotterdam-Los, D., Pallud, C., and Abell, J. (2006). Potential rates and pathways of microbial nitrate reduction in coastal sediments. FEMS Microbiol. Ecol. 58, 179-192.
Mayewski, P. A., Lyons, W. B., Spencer, M. J., Twickler, M. S., Buck, C. F., and Whitlow, S. (1990). An ice-core record of atmospheric response to anthropogenic sulfate and nitrate. Nature 346, 554-556.

Miletto, M., Loy, A., Antheunisse, A. M., Loeb, R., Bodelier, P. L., and Laanbroek, H. J. (2008). Biogeography of sulfate-reducing prokaryotes in river floodplains. FEMS Microbiol. Ecol. 64, 395-406.

Moller, A., Grahn, A., and Welander, U. (2004). Precipitation of heavy metals from landfill leachates by microbially-produced sulphide. Environ. Technol. 25, 69-77.

Morse, J. W. (1994). Release of toxic metals via oxidation of authigenic pyrite in resuspended sediments. Environ. Geochem. Sulfide Oxidation 550, 289-297.

Muyzer, G., and Stams, A. J. M. (2008). The ecology and biotechnology of sulphate-reducing bacteria. Nat. Rev. Microbiol. 6, 441-454.

Oremland, R. S., Kulp, T. R., Blum, J. S., Hoeft, S. E., Baesman, S., Miller, L. G., and Stolz, J. F. (2005). A microbial arsenic cycle in a salt-saturated, extreme environment. Science 308, 1305-1308.

Oren, A. (2011). Thermodynamic limits to microbial life at high salt concentrations. Environ. Microbiol. 13, 1908-1923.

Otte, S., Kuenen, J. G., Nielsen, L. P., Paerl, H. W., Zopfi, J., Schulz, H. N., Teske, A., Strotmann, B., Gallardo, V. A., and Jorgensen, B. B. (1999). Nitrogen, carbon, and sulfur metabolism in natural Thioploca samples. Appl. Environ. Microbiol. 65, 3148-3157.

Pallud, C., Meile, C., Laverman, A. M., Abell, J., and Van Cappellen, P. (2007). The use of flow-through sediment reactors in biogeochemical kinetics: methodology and examples of applications. Mar. Chem. 106, 256-271.

Pallud, C., and Van Cappellen, P. (2006). Kinetics of microbial sulfate reduction in estuarine sediments. Geochim. Cosmochim. Acta 70, 1148-1162.

Payne, E. K., Burgin, A. J., and Hamilton, S. K. (2009). Sediment nitrate manipulation using porewater equilibrators reveals potential for $\mathrm{N}$ and $\mathrm{S}$ coupling in freshwaters. Aquat. Microb. Ecol. 54, 233-241.

Philippot, L. (2002). Denitrifying genes in bacterial and Archaeal genomes. Biochim. Biophys. Acto 1577, 355-376.

Roychoudhury, A., Viollier, E., and Van Cappellen, P. (1998). A plug flowthrough reactor for studying biogeochemical reactions in undisturbed aquatic sediments. Appl. Geochem. 13, 269-280.

Schlesinger, W. H. (1997). Biogeochemistry: An Analysis of Global Change. San Diego: Academic Press, 588.

Schwermer, C. U., Ferdelman, T. G., Stief, P., Gieseke, A., Rezakhani, N., van Rijn, J., de Beer, D., and Schramm, A. (2010). Effect of nitrate on sulfur transformations in sulfidogenic sludge of a marine aquaculture biofilter. FEMS Microbiol. Ecol. 72, 476-484.

Schwientek, M., Einsiedl, F., Stichler, W., Stögbauer, A., Strauss, H., and Maloszewski, P. (2008). Evidence for denitrification regulated by pyrite oxidation in a heterogeneous porous groundwater system. Chem. Geol. 255, 60-67.

Seitzinger, S., Harrison, J. A., Böhlke, J. K., Bouwman, A. F., Lowrance, R., Peterson, B., Tobias, C., and Van Drecht, G. (2006). Denitrification across landscapes and waterscapes: a synthesis. Ecol. Appl. 16, 2064-2090.

Senga, Y., Mochida, K., Fukumori, R. Okamoto, N., and Seike, Y. (2006). $\mathrm{N} 2 \mathrm{O}$ accumulation in estuarine and coastal sediments: The influence of $\mathrm{H} 2 \mathrm{~S}$ on dissimilatory nitrate reduction. Estuar. Coast. Shelf Sci. 67, 231-238.

Sierra-Alvarez, R., Beristain-Cardoso, R., Salazar, M., Gómez, J., RazoFlores, E., and Field, J. A. (2007). Chemolithotrophic denitrification with elemental sulfur for groundwater treatment. Water Res. 41, 1253-1262.

Song, K., Lee, S. H., and Kong, H. (2011). Denitrification rates and community structure of denitrifying bacteria in newly constructed wetland. Eur. J. Soil Biol. 47, 24-29.

Sun, W. J., Sierra-Alvarez, R., Hsu, I., Rowlette, P., and Field, J. A. (2010). Anoxic oxidation of arsenite linked to chemolithotrophic denitrification in continuous bioreactors. Biotechnol. Bioeng. 105, 909-917.

Terbraak, C. J. F., and Verdonschot, P. F. M. (1995). Canonical correspondence-analysis and related multivariate methods in aquatic ecology. Aquat. Sci. 57, 255-289.

Thamdrup, B., Fossing, H., and Jorgensen, B. B. (1994). Manganese, iron, and sulfur cycling in a coastal marine sediment, Aarhus bay, Denmark. Geochim. Cosmochim. Acta 58, 5115-5129.

Vandenwollenberg, A. L. (1977). Redundancy analysis an alternative for canonical correlation analysis. Psychometrika 42, 207-219.

Wagner, M., Roger, A. J., Flax, J. L., Brusseau, G. A., and Stahl, D. A. (1998). Phylogeny of dissimilatory sulfite reductases supports an early origin of sulfate respiration. J. Bacteriol. 180, 2975-2982.

Wallenstein, M. D., Myrold, D. D., Firestone, M., and Voytek, M. (2006). Environmental controls on denitrifying communities and denitrification rates: insights from molecular methods. Ecol. Appl. 16, 2143-2152.

Westermann, P., and Ahring, B. K. (1987). Dynamics of methane production, sulfate reduction, and denitrification in a permanently waterlogged alder swamp. Appl. Environ. Microbiol. 53, 2554-2559.

Whitmire, S. L., and Hamilton, S. K. (2005). Rapid removal of nitrate and sulfate in freshwater wetland sediments. J. Environ. Qual. 34, 2062-2071.

Zhang, Y. H., Zhong, F. H., and Xia, S. Q. (2009). Effect of initial ph on autohydrogenotrophic denitrification. Fresenius Environ. Bull. 18, 2352-2358.

Zumft, W. G. (1997). Cell biology and molecular basis of denitrification. Microbiol. Mol. Biol. Rev. 61, 533-616.

Conflict of Interest Statement: The authors declare that the research was conducted in the absence of any commercial or financial relationships that could be construed as a potential conflict of interest.

Received: 12 December 2011; accepted: 29 January 2012; published online: 27 February 2012.

Citation: Gu C, Laverman AM and Pallud CE (2012) Environmental controls on nitrogen and sulfur cycles in surficial aquatic sediments. Front. Microbio. 3:45. doi: 10.3389/fmicb.2012.00045

This article was submitted to Frontiers in Terrestrial Microbiology, a specialty of Frontiers in Microbiology.

Copyright (c) 2012 Gu, Laverman and Pallud. This is an open-access article distributed under the terms of the Creative Commons Attribution Non Commercial License, which permits noncommercial use, distribution, and reproduction in other forums, provided the original authors and source are credited. 